Dina Kh. Krasnoselskaya Ufa State Petroleum Technological University, Ufa, Russian Federation http://orcid.org/0000-0002-1668-2937, e-mail: dina-hamzina@mail.ru

\title{
Examining Regional Polycentricity: Does It Really Matter in Transitional Russia?
}

In the normative agenda of European countries, polycentricity is considered a desirable spatial form for encouraging regional competitiveness and territorial cohesion. Since the collapse of the Soviet Union, Russian regions have undergone various reforms aimed at reducing tremendous social-economic differentiation, but the results of applied strategic plans were moderate. According to the existing Spatial Development Strategy of the Russian Federation, polycentric patterns are encouraged to increase the quality of economic space and its connectivity. Using statistical data from 2017 for 271 Russian municipalities, the research addresses the impact of socio-economic determinants and road infrastructure on the spatial structure. The Republic of Bashkortostan and six adjacent regions served as a case study. Conducted regression analysis identified key variables that influence polycentricity, upon which global and local Moran's indexes were calculated to reveal the potential for intraregional cooperation. Research findings showed that polycentricity in its morphologic nature is positively determined by economic variables (namely, the value of shipped goods, performed works and services) and social infrastructure (the number of doctors per 10000 inhabitants) while spatial autocorrelation is weak both within and beyond regional boundaries. The results may be used for formulating regional policies, infrastructure programmes, and spatial planning.

Keywords: polycentricity, spatial autocorrelation, employment density, economic development, social infrastructure, road infrastructure

\section{Acknowledgements}

The author would like to thank anonymous reviewer for insightful and invaluable comments. Any remaining errors are my own.

For citation: Krasnoselskaya, D. Kh. (2021). Examining Regional Polycentricity: Does It Really Matter in Transitional Russia? Ekonomika regiona [Economy of region], 17(2), 389-401, https://doi.org/10.17059/ekon.reg.2021-2-3

\footnotetext{
1 (c) Krasnoselskaya, D. Kh. Text. 2021.
} 
ИССЛЕДОВАТЕЛЬСКАЯ СТАТЬЯ

Д. Х. Красносельская

Уфимский государственный нефтяной технический университет, Уфа, Российская Федерация http://orcid.org/0000-0002-1668-2937; e-mail: dina-hamzina@mail.ru

\section{Оценка значимости региональной полицентричности для России переходного периода}

В европейских странах полииентричность рассматривается как оптимальная пространственная структура, обеспечивающая региональную конкурентоспособность и территориальное взаимодействие. После распада Советского Союза в России были проведены многочисленные реформы, направленные на преодоление региональной социально-экономической дифференииации, которые, однако, не привели к значительным результатам. Существующая Стратегия пространственного развития Российской Федерации способствует распространению полицентрических моделей для повышения качества и связанности экономического пространства. На основе статистических данных за 2017 г. проанализировано влияние показателей социально-экономического развития и дорожной инфраструктуры 271 российского муниципалитета на пространственную структуру. Исследование проводилось на примере Республики Башкортостан и шести прилегающих к ней регионов. Регрессионный анализ выявил ключевые переменные, влияющие на полицентричность, на их основе были рассчитаны глобальные и локальные индексы Морана для определения возможности внутрирегиональной кооперации. Вычисления показали, что на полицентричность положительно влияют экономические переменные (стоимость отгруженных товаров, выполненных работ и услуг) и сочиальная инфраструктура (количество врачей на 10000 жителей); слабая пространственная автокорреляиия наблюдается и внутри регионов и за их пределами. Результаты исследования могут быть использованы для разработки региональной политики, инфраструктурных программ и планов пространственного развития.

Ключевые слова: полицентричность, пространственная автокорреляция, плотность занятости, экономическое развитие, социальная инфраструктура, дорожная инфраструктура

\section{Благодарность}

Автор выражает благодарность анонимному рецензенту за содержательные комментарии. Все оставшиеся в статье очибки - авторские.

Для цитирования: Красносельская Д. Х. Оценка значимости региональной полицентричности для России переходного периода // Экономика региона. 2021. Т. 17, вып. 2. С. 389-401. https://doi.org/10.17059/ekon.reg.2021-2-3

\section{Introduction}

The first reference to the term «polycentricity» in normative plans is found in the European Spatial Development Perspective (ESDP) released in 1999. There was a strong need for the implementation of spatial tools and mechanisms to counterbalance the development of the European Union (EU) key centres, including the metropolises of London, Paris, Milan, Munich, and Hamburg, having $40 \%$ of the EU's population, accounted for $50 \%$ of the EU's gross domestic product (GDP). The main goal of the ESDP is to achieve a balanced and sustainable development by strengthening economic and social cohesion. The collaborative measures include common agricultural policy, environment policy, research, and technological development. The basic assumption in forming an effective cooperation network is a complementarity or regions' ability to complement each other and cooperate. The complementarity is manifested through the distribution of such functions as culture, education, knowledge, and social infrastructure.

The concept of polycentricity and its applications at different scales are widely discussed across advanced and developing economies (Salvati, Carlucci, Grigoriadis \& Chelli [1]; Knaap,
Ding, Niu \& Mishra [2], Murakami \& Chang [3]). In the Russian Federation, the issues of polycentric development are becoming popular due to a crucial need to establish spatial development policies to increase the sustainability of the existing regional structure.

Polycentricity has been highlighted in the Spatial Development Strategy of Russia as a spatial structure made up of equal distribution centres within a national economy. Despite numerous insightful studies on polycentricity and its implementation at different geographic scales in European countries, the concept remains rather «fuzzy» in theory. This paper focuses on the polycentric development at the intraregional level; a municipality is considered an initial territorial unit of regional analysis within administrative demarcation in Russia. The research aims to shed some light on the impact of the municipality's economic development, road and social infrastructure on polycentricity in terms of employment density. These indicators are taken into consideration due to assumptions rooted back in Alonso's theory [4] postulating that advanced infrastructure makes possible the benefits of polycentric development; the infrastructure de- 
termines the possibilities of decentralisation, employment and economic activities. The well-developed infrastructure facilitates a firm's interactions by reducing transportation and information costs. On the other hand, transport infrastructure supports the commuting and trade flows between core and periphery. This study represents a two-steps technique aimed at 1) identification of key regional determinants driving polycentricity in municipalities; 2) evaluation of spatial effects based on the first step determinants.

The basic findings showed a strong relationship between polycentricity and economic development of the municipality in most examined regions. Furthermore, such an indicator as the number of doctors for 10,000 inhabitants is closely related to polycentricity. To assess spatial effects, Moran's global and local autocorrelation indexes were applied. I identified high-high and low-low areas related to social infrastructure and investment in fixed assets to determine potential boundaries for interregional cooperation.

My research contributes to the existing body of literature in two ways. Firstly, it enriches empirical evidence by testing the hypothesis of whether the indicators of economic development, investments, and social and road infrastructure affect polycentricity in emerging Russia. Present studies on polycentric issues deal with a) polycentricity effects on territory's economic development; b) descriptive analysis of commuting and settlement patterns. This paper relates to fast-growing literature that focuses on the effects of regional economic conditions on polycentricity. China \& Liu [5] examined the influence of spatial structure on economic productivity measured in terms of the capita GDP of a city and proposed regression models that presented an uncertain picture of the effects of spatial structure on urban productivity. Kanai \& Schindler [6] researched how polycentric urban expansion affected infrastructure networks; they proved that project-led polycentrism accumulating major investments attributed to secondary nodes did not decentralise planning power. Rauhut \& Komornicki [7] applied a multivariate cross-section regression model to estimate the impact of polycentrism on low-, medium-, and high-centrality social services. Their results showed no positive relationships between polycentrism and these variables. Present research follows a similar path by highlighting economic and social development factors that influence polycentricity.

Secondary, paper adds to a large body of literature focused on the descriptive analysis of commuting (Vasanen [8]; Dadashpoor, Afaghpoor \& Allan [9]; Zhong, Schläpfer, Müller Arisona,
Batty, Ratti \& Schmitt [10]) and employment patterns (Krehl [11]; Schmitt, Volgmann, Münter \& Mitchell [12]; Zambon, Serra, Grigoriadis, Carlucci \& Salvati [13]). My research contributes to this emerging body of literature and examines spatial horizontal ties to determine perspective regional centres in terms of investment and social infrastructure to boost intraregional cooperation and interaction.

The rest of the article is organised as follows. Section 2 reveals the theoretical background and regional identities of the Russian spatial structure. Section 3 presents the study area and data. Section 4 includes methodology. Section 5 reveals empirical results and interpretations. Section 6 contains concluding remarks.

\section{Theoretical Background and the Case of Russia}

Traditionally, the understanding of polycentricity as many independent separately organised centres is not new in regional science. The main assumption of polycentricity is about forming the set of independent spatially linked centres with sufficient critical mass to provide positive spatial effects comparable to the large metropolitan area, while such typical agglomeration problems as pollutions, traffic, high land value are missing. In general, the issues of centre interactions are traced back to Christaller's and Lösch's foundation works in which hierarchical links between centres were examined in terms of flows of goods and services. Recent studies attempt to capture the reasons and mechanisms of urban sprawl at different scales supported by decentralisation of settlement patterns and economic activities. The increasing mass of private cars, boosting the development of transport systems allowed people to leave central business districts and settle down in suburban areas. Therefore, the hierarchy-orientated model of interactions between core and periphery lost its relevance, and the emphasis was shifted to exploring the emerging network (polycentric) spatial structure.

The existing practice of applying this concept shows diverse results of implementation at different scales. However, at the national level it was put into the normative field, at the regional level it was mostly used analytically [14].

It is possible to distinguish at least three approaches that deal with polycentricity. The first one is a morphological approach that concentrates on descriptive analysis of subcentres and centres emerging in suburban areas. For instance, Ruguelle, Thomas \& Verhertsel [15] detected clusters of employment for four urban regions 
in Belgium using the Hoover and Moran's indices. Their findings revealed that polycentrism was still weak and employment centres of the four cities were rare and closely linked to historical landmarks. Aguilera \& Mignot [16] distinguished two types of subcentres: suburban subcentres nearly located in the city centre and outlying subcentres situated on the main transport axes. According to research results, these subcentres were not able to resist diffused sprawl of residences beyond them. The latest studies exploit various methods of identifying urban density. To measure polycentricity, Taubenböck, Standfuß, Wurm, Krehl \& Siedentop [17] applied a physical approach involving a large area of 3D building models based on sensitive data.

Another line of research addresses functional polycentricity. Parr [18] analyses a phenomenon of the polycentric urban region (PUR) by specifying its essential characteristics, including clustering of centres, centre specialisation, the size distribution of centres and interaction among them emerge. Interaction includes commuting patterns, flows of goods and services. Parr has found that trade within the PUR is not hierarchically restricted. For instance, a centre of medium size may export goods and services both to a centre of comparable size and to one of greater size. Limtanakool, Schwanen \& Dijst examine a spatial organisation of the economic activities in advanced economies. They consider three journey purposes, namely, business, holiday, and leisure. The authors studied patterns of interaction between functional urban areas (FURs) in France and Germany by developing the three dimensions of interaction (strength, symmetry, and structure).

Vasanen [19] explores connectivity fields as a measure of functional polycentricity. The connectivity field of a distinct centre presents the distribution of origins of direct flows (commuting, shopping trips, telephone, and email traffic etc.) to the centre. He used commuting data to measure the degree of functional interactions across three different scales. Vasanen confirmed the scale-dependent character of polycentricity; the higher the spatial scale, the lower degree of functional balance. Yang, Wang, Bai \& Han [20] focus on the dependence between urban forms in terms of «polycentricity-monocentricity» and commuting patterns. The authors study commuting distances, car mode share, commutes inside the subcentres to provide detailed empirical data related to transport outcomes and travel patterns. Hu, Sun \& Wang [21] investigate the effect of changing urban structure on commuting patterns in China. They consider emerging-, persisting-, and non-centre territories, examining spatial evolution.

At last, third research group explores issues of polycentric development in the context of its impact on different territorial indicators such as culture, leisure, sports amenities, gross domestic product, housing prices, etc. Maijers [22] tests the hypothesis of whether a polycentric urban region can provide cultural, leisure, and sports amenities to a similar extent as a monocentric city-region in 42 Dutch regions. His study proved the negative relationship between the extent of polycentricity and presented amenities.

Brezzi \& Veneri [23] explored polycentricity at three different spatial scales in the Organisation for Economic Co-operation and Development (OECD) countries (metropolitan, regional and national levels) to find out whether polycentricity affects economic development. The findings proved the scale-dependent character of polycentricity and showed a mixed picture: at the national level, OECD countries with a more polycentric urban structure demonstrated higher GDP per capita. Conversely, at the regional scale, more monocentric regions have higher GDP per capita in comparison with more polycentric counterparts.

Wen \& Tao [24] try to model how housing price is determined by a building's age, neighbourhood, location characteristics, and polycentric urban structure. They emphasised the spatial dependence on housing prices. Moreover, the emerging polycentric urban structure had a significant impact on housing prices.

The collapse of the Soviet Union greatly transformed the spatial structure in Russia. Having pre-existing ties, regions turned into fragmented, deeply different parts of a national entity. Governmental reforms aimed at strengthening the interaction between regions and reducing economic disparities showed moderate results [25, 26]. In 2018, the gap between the most and least developed regions in terms of shipped own production, performed works and services was 721 times, investment in fixed assets -229 times. The transition to a market economy was more favourable for diversified export-oriented regions; old traditional industrial regions lost their place in the overall system of economic ties. In this regard, Russia is of particular interest due to two reasons. Firstly, Soviet reforms were primarily aimed at boosting industrial development and the return on investment; settlement patterns were regarded as an essential part of the labour force, while matters of social and road infrastructure development were almost ignored. The latest reforms in spatial planning showed a shift in focus to strengthening 
social and road infrastructure, increasing the quality of people's well-being. Thus, a rather strong relationship between the level of polycentricity and gross regional product (GRP) per capita and investments is expected. Furthermore, I am interested in exploring the effects of social and road infrastructure on polycentricity. Secondly, the potential for interregional cooperation is still weak due to the lack of joint projects and regional programmes beyond traditional administrative boundaries. Thus, the absence of positive spatial autocorrelation regarding key factors driving polycentric development beyond regions is assumed. To summarise the above mentioned, Russian regions have undergone a series of economic reforms that significantly affected the spatial structure; their outcomes present an unclear picture. Therefore, there are reasons to assume that polycentricity is dependent on economic development, investments, social and road infrastructure.

\section{Data and Descriptive Statistics}

Before data and methodology description, to facilitate comprehension, it is necessary introduce administrative structure in Russia. The Russian Federation consists of eight Federal Districts (the first administrative level) including 85 regions (the second level). Regions, in their turn, are divided into municipalities (the third administrative level). The Republic of Bashkortostan and six adjacent regions serve as a case study.

This analysis uses data on 271 municipalities in six regions. The Sverdlovsk region is adjacent

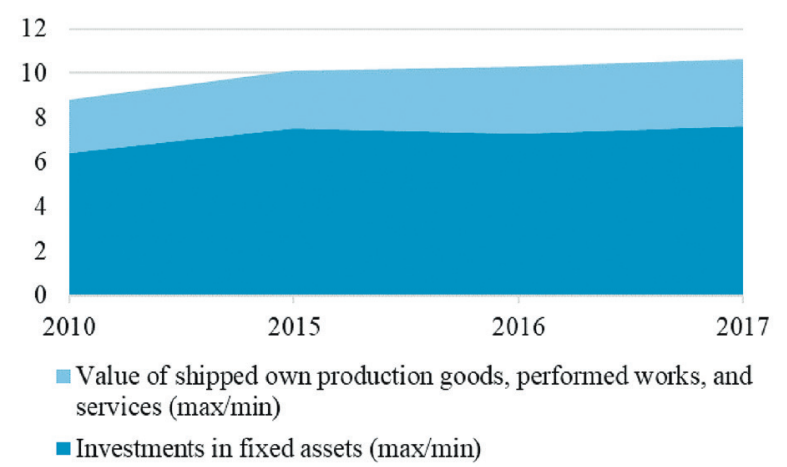

Fig. 1. Inter-regional differentiation (max/min ratios) Source: Rosstat statistics (processed by the author)

to the Republic of Bashkortostan, but it was excluded from analysis because of missing data. Among case regions, the Republic of Tatarstan is in the top twenty of most economically developed regions in the country. There is significant spatial heterogeneity within the research area; only $8.9 \%$ of the total number of municipalities covers 90$99 \%$ of total employment. To provide a deep understanding of spatial differentiation in economic variables, the data were presented at both the intra-regional (Table l) and cross-regional levels (Figure 1). This diagram demonstrates differentiation between the most and less developed regions in terms of the value of shipped own production, performed works and services, and investments in fixed assets.

Figure 1 and Table 1 show that the inter-regional differentiation attributed to investments in fixed assets, and the value of shipped own produc-

Table 1

Descriptive statistics of variables (across municipalities)

\begin{tabular}{|c|c|c|c|c|c|c|}
\hline Category & Variable definition & Variable & Mean & Min & $\operatorname{Max}$ & $\begin{array}{c}\text { Coefficient of } \\
\text { variation, } \%\end{array}$ \\
\hline \multirow{2}{*}{$\begin{array}{l}\text { Economic } \\
\text { development }\end{array}$} & $\begin{array}{l}\text { Value of shipped own production } \\
\text { goods, performed works and services, } \\
\text { million roubles }\end{array}$ & prod & 32781,10 & 16,40 & 1070397,82 & 347,19 \\
\hline & $\begin{array}{l}\text { Investments in fixed assets million } \\
\text { roubles }\end{array}$ & inv & 5010,45 & 184388,4 & 8,4 & 372,35 \\
\hline \multirow{5}{*}{$\begin{array}{l}\text { Social infra- } \\
\text { structure }\end{array}$} & $\begin{array}{l}\text { Number of hospital beds per } 10,000 \\
\text { persons }\end{array}$ & beds & 46,48 & 4,10 & 144,10 & 46,97 \\
\hline & Number of doctors per 10,000 persons & $d o c$ & 24,78 & 2,80 & 89,20 & 41,41 \\
\hline & $\begin{array}{l}\text { Number of middle-level medical } \\
\text { personnel per } 10,000 \text { persons }\end{array}$ & nurs & 93,39 & 883,30 & 36,50 & 57,99 \\
\hline & $\begin{array}{l}\text { Provision of housing (average total floor } \\
\text { space per person, in square meters) }\end{array}$ & hous & 26,10 & 14,10 & 48,30 & 26,89 \\
\hline & $\begin{array}{l}\text { Access of children to pre-school or pre- } \\
\text { primary educational establishments, } \\
\text { places for } 1,000 \text { children }\end{array}$ & kgard & 840,03 & 381,00 & 1450,00 & 24,32 \\
\hline $\begin{array}{l}\text { Road infra- } \\
\text { structure }\end{array}$ & $\begin{array}{l}\text { The proportion of motorway with } \\
\text { hard surface in the overall length of } \\
\text { highways, percent }\end{array}$ & roads & 74,79 & 26,60 & 100,00 & 15,20 \\
\hline
\end{tabular}

Source: Rosstat statistics (processed by the author). 
tion goods, performed works, and services is much lower than the inter-municipal one.

Data presented in Table 1 indicate significant disparities in economic development variables within municipalities. It can be explained by the dominance of traditional industrial centres with well-developed transportation infrastructure attracting large-scale investments. However, the spatial disparities in social and road infrastructure are substantially narrower due to government policy programmes adopted recently.

The recent empirical developments, concerning the examined concept, present various methods for polycentricity measuring, which are primarily dependent on engaged morphological or functional approach. A morphological approach was chosen for this study, as it explores employment or population density as polycentric dimensions. First, this concept was originally designed in an attempt to explain the reasons for urban sprawl characterised by the extension of settlement or employment patterns beyond administrative urban boundaries caused by the dramatic increase in the number of automobiles. It has traditionally been applied to the meso-level of urban agglomeration focusing on intra-urban patterns of clustering of people and economic activity in Los Angeles, Paris and London [14].

Second, the pivotal issue in the polycentricity studies is that while metropolitan areas are becoming decentralised, the central business districts are losing centrality in terms of employment.

As for calculation algorithms attributing to polycentric patterns, I can distinguish different techniques. Ruguelle, Thomas \& Verhertsel [15] measure polycentricity using the Hoover index, which compares the distribution of a variable $X$ with the distribution of a variable $Y$ (equation 1):

$$
I_{h}=\frac{1}{2}\left(\sum_{i=1}^{m}\left|X_{i}-Y_{i}\right|\right)
$$

$I_{h}$ - Hoover index; $i$ - number of areas under consideration; $X_{i}$ - employment in the $i$-area; $Y_{i}-$ total surface of the $i$-area.

This indicator shows what share of employment should be redistributed to achieve equivalence over the entire examined territory.

Veneri \& Burgalassi [27] quantify the morphological polycentricity with the ratio of people living in the main city over total population in the region, as shown in equation 2: the higher the weight, the higher the monocentricity of the region.

$$
\text { weight }=\frac{\operatorname{pop}(c)}{\sum_{n=1}^{N} \operatorname{pop}(n)},
$$

weight - share of the main city in the total population in the region; $p o p(c)$ - population in the main city; $\operatorname{pop}(n)$ - population in the region.

However, the Hoover index and population ratios cannot predict a hierarchical asymmetry across centres; thus, a rank-size approach, which is rooted in Zipf's Law, gained great popularity [28]. This approach ranks cities to in the region according to their population (rank) and then equation 3 is estimated:

$$
\ln p o p=\alpha+\beta \ln r a n k .
$$

The slope of the equation reflected by the $\beta$-coefficient indicates the polycentricity level in the region: the higher the value of $\beta$-coefficient, the higher the polycentricity. The main disadvantage of this approach is that it should be based on the same number of centres in cities to make the comparison adequate.

Thus, concentration of employment density in 2017 was used as a measure of polycentricity in Russian regions (following Veneri \& Burgalassi [27]) due to its simplicity and available data. Furthermore, the centres' hierarchy is out of the research focus, a rank-size approach is not necessary. At present, most of the European studies deal with centre-identifying matters in large metropolitan areas interlinked by commuting patterns. In this research, municipalities are considered as centres of employment density.

To calculate the concentration of employment density, I divided municipal density by overall employment related to the region as a whole. A morphological approach was chosen for the following reasons. Firstly, there is no data on communing patterns. Secondly, the regional structure of territorial units under consideration demonstrates a large spatial heterogeneity and weak connectivity. Thus, application of the functional approach involves a search for appropriate polycentricity measures substantially different from the ones used in foreign countries.

To assess economic development, two variables were chosen: the volume of shipped goods, performed works and services, and investments in fixed assets. To determine social infrastructure, variables attributed to medical and childcare services are used. Issues of road infrastructure are especially important because of the length and vast geographic area covered by the country. 


\section{Methodology}

\subsection{Empirical Model Specification}

This research analyses the dependence between regional polycentricity measured through population density in municipalities and variables related to economic performance and social and road infrastructure, using the next multiple regression (equation 4):

$$
\begin{gathered}
P=\alpha_{0}+\alpha_{1} \text { prod }+\alpha_{2} \text { inv }+\alpha_{3} \text { beds }+ \\
+\alpha_{4} \text { doc }+\alpha_{5} \text { nurs }+\alpha_{6} \text { hous }+\alpha_{7} \text { kgard }+ \\
+\alpha_{8} \text { road }+\alpha_{9} \text { square }+\varepsilon .
\end{gathered}
$$

where $P$ is the measure of morphological polycentricity (municipality's employment concentration); prod, inv, beds, doc, nurs, hous, kgard, road the set of the above presented variables (Section 3); $\alpha_{0}-$ the constant term; $\alpha_{1}-\alpha_{9}-$ coefficients to be estimated; $\varepsilon-$ the error term. To account for location characteristics of municipalities the dummy variable square was added.

\subsection{Spatial Autocorrelation Analysis}

Spatial analysis is applied to test the hypothesis on a correlation between neighbouring municipalities. This method of spatial econometrics is widely used in studies devoted to regional disparities [29, 30, 31]. Moreover, local indicators of spatial autocorrelation (LISA) measure the (dis) similarity between spatial units to identify employment subcentres. Moran's global autocorrelation index is a widespread indicator of global spatial autocorrelation; it can be calculated as follows (equation 5):

$$
I_{m}=\frac{N}{\sum_{i} \sum_{j} w_{i j}} \times \frac{\sum_{i} \sum_{j} w_{i j}\left(x_{i}-\mu\right)\left(x_{j}-\mu\right)}{\sum_{i}\left(x_{i}-\mu\right)^{2}},
$$

where $N$ is the number of municipalities; $x_{i}$ - the examined indicator; $\mu-$ the mean of the examined indicator; $w_{i j}$ - elements of the spatial weight matrix for the $i$-th and $j$-th municipalities.

The value of Moran's index should be compared with the expected value $\left.E\left(I_{m}\right)\right)=-1 /(n-1)$.

$I_{m}>E\left(I_{m}\right)$ indicates a positive spatial autocorrelation because of similar values of the examined indicator in the neighbouring municipalities. $I_{m}<\mathrm{E}\left(I_{m}\right)$ shows a negative spatial autocorrelation, meaning that the values are quite different. $I_{m}=$ $=\mathrm{E}\left(I_{m}\right)$ demonstrates a spatially random character of data.

In general, the spatial weight matrix reveals the existence of a neighbour relation as a binary relationship expressing it by weights 1 and 0 . If $i$-th and $j$-th municipalities are neighbours then $w_{i j}=1$, otherwise $w_{i j}=0$.

Next, to identify local clusters, I determined the local indicator of spatial autocorrelation (LISA) and local spatial outliers (equation 3):

$$
L_{I_{m i}}=N \frac{\left(x_{i}-\bar{x}\right) \sum_{i} \sum_{j} w_{i j}\left(x_{j}-\bar{x}\right)}{\sum_{i}\left(x_{i}-\bar{x}\right)^{2}},
$$

Local Moran's index makes it possible to discover hot spots, cold spots and spatial outliers in the data. If $L_{I, i}<0$, there is a negative autocorrelation for the municipality, meaning that this territory differs significantly from the neighbouring territories (outlier). If $L_{I_{m i}}>0$, the autocorrelation is positive, the given territory is similar in value to the neighbouring territories (cluster).

The municipalities can be divided into the next four groups of cluster cores according to the value of local Moran's index:

1. High-high location patterns, showing the existence of positive autocorrelation caused by high values of the examined indicator in the municipality and surrounding territories.

2. Low-low cluster cores, indicating positive autocorrelation. The municipalities having relatively low values of the examined indicator are surrounded by the neighbouring territories with similar values.

3. High-low location patterns, occurring when territories with high values of the indicator are surrounded by neighbouring municipalities with dissimilar values. In this case, negative autocorrelation is diagnosed.

4. Low-high clusters cores, characterised by low values in the given municipality surrounded by neighbouring locations with dissimilar values. Autocorrelation is negative.

This technique enables both the exploration of areas with particularly high levels of spatial dependence (i.e., hot spots) and identification of regional identities. Furthermore, to assess polycentricity, I will use the standard deviation related to employment density in municipalities.

\section{Empirical Results and Interpretations}

\subsection{Regression Model Estimation}

I constructed a regression model of the dependence of polycentricity from economic and infrastructure determinants using the data for 2017. All control variables were estimated using SPSS Statistics 23 (Table 2).

Observed variance results of all six models are statistically significant for F-test and t-test sta- 
Impacts of model factors on polycentricity (regressions results)

\begin{tabular}{|c|c|c|c|c|c|c|}
\hline Model factors & $\begin{array}{c}\text { Chelyabinsk } \\
\text { region }\end{array}$ & $\begin{array}{c}\text { Republic of } \\
\text { Bashkortostan }\end{array}$ & $\begin{array}{c}\text { Republic of } \\
\text { Tatarstan }\end{array}$ & $\begin{array}{c}\text { Perm } \\
\text { region }\end{array}$ & $\begin{array}{c}\text { Orenburg } \\
\text { region }\end{array}$ & $\begin{array}{c}\text { Udmurt } \\
\text { Republic }\end{array}$ \\
\hline prod & 0.728 & 0.990 & 0.075 & 0.944 & 0.210 & 0.089 \\
inv & -0.075 & -0.039 & -0.051 & -0.028 & 0.052 & 0.830 \\
beds & 0.035 & 0.017 & -0.011 & -0.009 & 0.117 & 0.013 \\
doc & 0.376 & 0.029 & 0.947 & 0.074 & 0.091 & -0.070 \\
nurs & -0.101 & -0.050 & -0.184 & -0.005 & -0.074 & 0.048 \\
hous & 0.010 & 0.011 & -0.072 & -0.005 & -0.270 & -0.044 \\
rgard & 0.004 & 0.004 & -0.082 & -0.009 & 0.040 & 0.048 \\
square & -0.031 & 0.008 & 0.100 & -0.017 & -0.006 & 0.076 \\
\hline Adjusted $R^{2}$ & 0.057 & 0.025 & -0.012 & -0.004 & 0.694 & -0.062 \\
\hline Standard error of regression & 0.921 & 0.977 & 0.885 & 0.972 & 0.934 & 0.991 \\
\hline F-test & 0.014 & 0.005 & 0.017 & 0.009 & 0.010 & 0.008 \\
\hline Darbin-Watson statistic & 2.376 & 1.915 & 1.950 & 1.720 & 2.232 & 1.754 \\
\hline
\end{tabular}

* Note: Statistically significant at the 0.01 level.

Source: processed by the author using IBM SPSS Statistics 23.0.

tistics at the 0.01 significance level. The DurbinWatson statistic reveals the absence of autocorrelation in the residuals. These results show that the models are valid. Adjusted $R^{2}$ values indicate that regression equations account for $99.1 \%$ to $88.5 \%$ of the variation of the dependent variable, providing a good fit. According to the data presented in Table 1, there is a positive correlation between polycentricity and value of shipped own production, performed works and services. Among the social infrastructure measures, a positive relationship was found between polycentricity and the number of doctors per 10,000 persons in all regions except for the Udmurt Republic. On the one hand, it can be explained by the persistence of the spatial structure where labour and industrial production are closely interrelated since the plans for the placement of productive forces. On the other hand, it demonstrates the results of the national healthcare programme «Provincial doctor» primarily focused on ensuring medical care in rural areas across the country. Conversely, the number of middle-level medical personnel has negative relationships with polycentricity in five regions. This result indicates a decrease in the number of nurses in the country and reveals disparities in the medical care system.

The rest of variables showed a mixed picture. For instance, the variable relating to road infrastructure has a positive impact on polycentricity in the two most polycentric regions and the Udmurt Republic, but it is negatively correlated with polycentricity in other regions. A transport network is a basic prerequisite for the reduction of differences in economic and social development and developing intra-regional linkages. To deepen this analysis, I ranked the examined regions ac-
Table 3

\begin{tabular}{|l|c|c|}
\hline \multicolumn{1}{|c|}{ Region's polycentricity rank } \\
\hline $\begin{array}{l}\text { Region } \\
\text { region }\end{array}$ & $\begin{array}{c}\text { Standard deviation of } \\
\text { employment density }\end{array}$ & $\begin{array}{c}\text { Polycentricity } \\
\text { rank }\end{array}$ \\
\hline $\begin{array}{l}\text { Republic of } \\
\text { Bashkortostan }\end{array}$ & 0.050927 & 5 \\
\hline $\begin{array}{l}\text { Republic of } \\
\text { Tatarstan }\end{array}$ & 0.035542 & 1 \\
\hline Perm region & 0.050848 & 3 \\
\hline $\begin{array}{l}\text { Udmurt } \\
\text { Republic }\end{array}$ & 0.088614 & 4 \\
\hline $\begin{array}{l}\text { Orenburg } \\
\text { region }\end{array}$ & 0.040758 & 6 \\
\hline
\end{tabular}

Source: processed by the author.

cording to the level of polycentricity by calculating the standard deviation of employment density (Table 3): the smaller the standard deviation of employment density, the more the polycentric spatial structure, and vice versa.

A closer look at the three most polycentric regions allowed me to draw the following conclusions. The most polycentric spatial structure of the Republic of Bashkortostan is mainly dependent on its industrial production. The less polycentric structure of the Orenburg region is determined by social and economic factors. Among all regions, the Republic of Tatarstan is considered to be leading in economic development due to its diversified production and well-developed transport infrastructure. The results show the strong dependence between its social characteristics and spatial structure. Thus, polycentricity drivers in the most economically advanced region of our case study tend to be more social rather than economical. 
Global Moran's indexes

\begin{tabular}{|c|c|c|c|}
\hline Variable & $\begin{array}{l}\text { Moran's } \\
\text { statistic }\end{array}$ & $\begin{array}{l}\text { Number of the municipalities } \\
\text { belonging to High-High cluster }\end{array}$ & $\begin{array}{l}\text { Number of the municipalities belonging to } \\
\text { Low-Low cluster }\end{array}$ \\
\hline$d o c$ & 0.023 & $\begin{array}{l}4 \text { (Orenburg region) } \\
1 \text { (Udmurt Republic) } \\
1 \text { (Perm region) }\end{array}$ & $\begin{array}{l}3 \text { (Perm region) } \\
6 \text { (Chelyabinsk region) } \\
2 \text { (Republic of Tatarstan) }\end{array}$ \\
\hline prod & -0.009 & 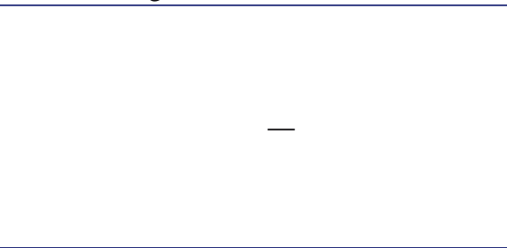 & $\begin{array}{l}3 \text { (Perm region) } \\
2 \text { (Chelyabinsk region) } \\
7 \text { (Republic of Bashkortostan) } \\
2 \text { (Orenburg region) } \\
4 \text { (the Republic of Tatarstan) } \\
1 \text { (Udmurt Republic) }\end{array}$ \\
\hline $\operatorname{Inv}$ & 0.010 & $\begin{array}{l}3 \text { (Perm region) } \\
26 \text { (Republic of Tatarstan) }\end{array}$ & $\begin{array}{l}8 \text { (Perm region) } \\
7 \text { (Chelyabinsk region) } \\
8 \text { (Orenburg region) } \\
13 \text { (Republic of Bashkortostan) } \\
1 \text { (Udmurt Republic) }\end{array}$ \\
\hline
\end{tabular}

Source: processed by the author.

\subsection{Spatial Autocorrelation Analysis}

In the previous step, the main polycentricity drivers were determined: the value of shipped own production, performed works and services, and the number of doctors. At this stage, I try to identify cluster cores attributed to these indicators. Concerning the shipped own production goods, performed works and services, the value of the global Moran's index is $-0.009\left(E\left(I_{m}\right)=-0.0037\right)$ reflecting virtually non-existent spatial autocorrelation in the case study in general. At the same time, according to the local Moran's indexes, lowlow and low-high cluster patterns in the Udmurt Republic (Figure 2) were observed demonstrat- ing the removal of resources from hinterland municipalities.

To test the hypothesis on a relationship between municipalities, I calculated global Moran's indexes using Geo Da software (table 4).

Figure 3 presents the spatial patterns of doct variable. Spatially fragmented cluster cores having low-low values are located in the Chelyabinsk, Perm regions, and the Republic of Tatarstan. Conversely, high-high location patterns are identified in the Udmurt Republic, as well as in the Orenburg and Perm regions. In the context of the polycentric development paradigm, this indicator could be referred to as low-centrality public ser-

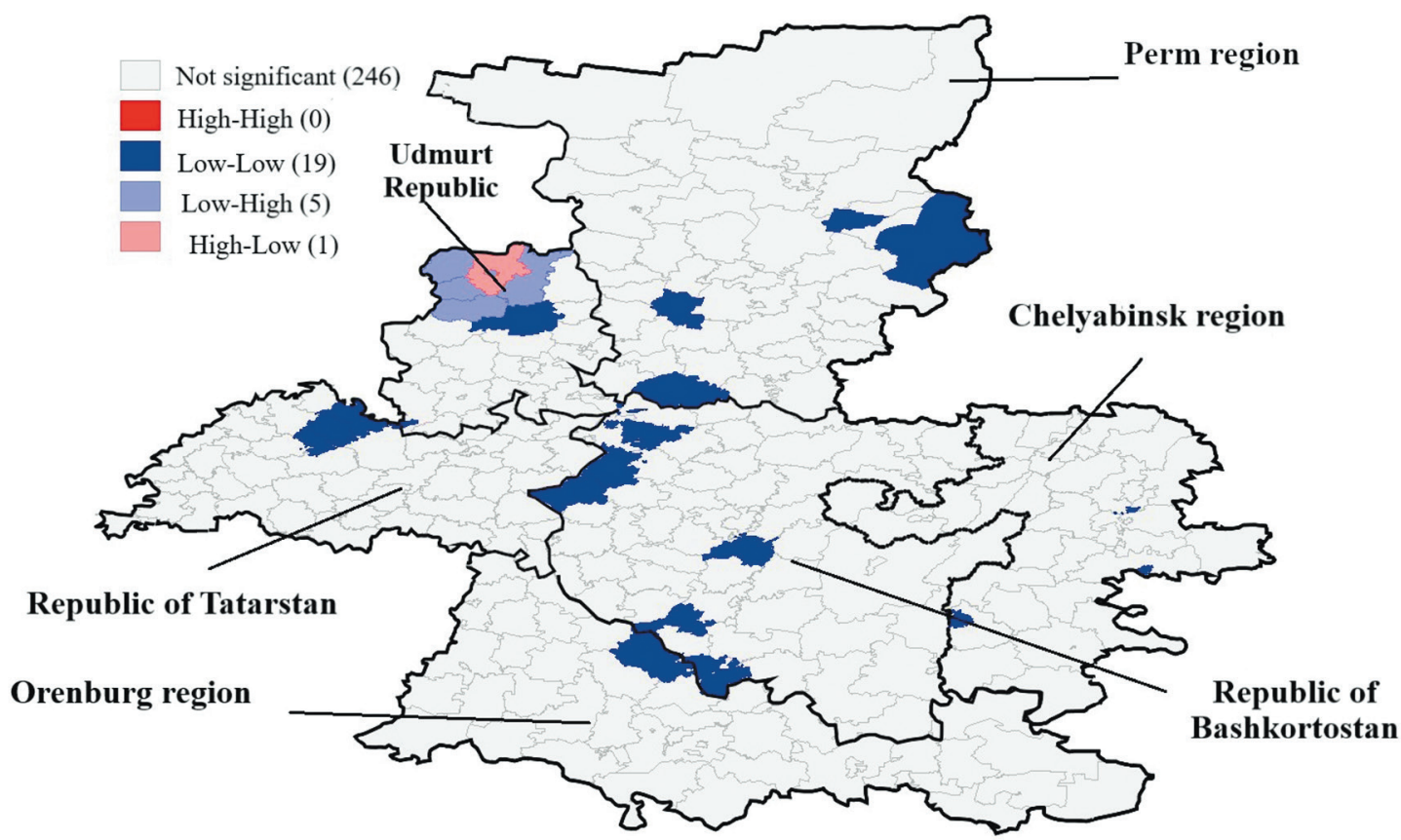

Fig. 2. The value of shipped own production goods, performed works, and services: LISA cluster map ( $p<0.05)$. Source: Rosstat statistics (processed by the author) 


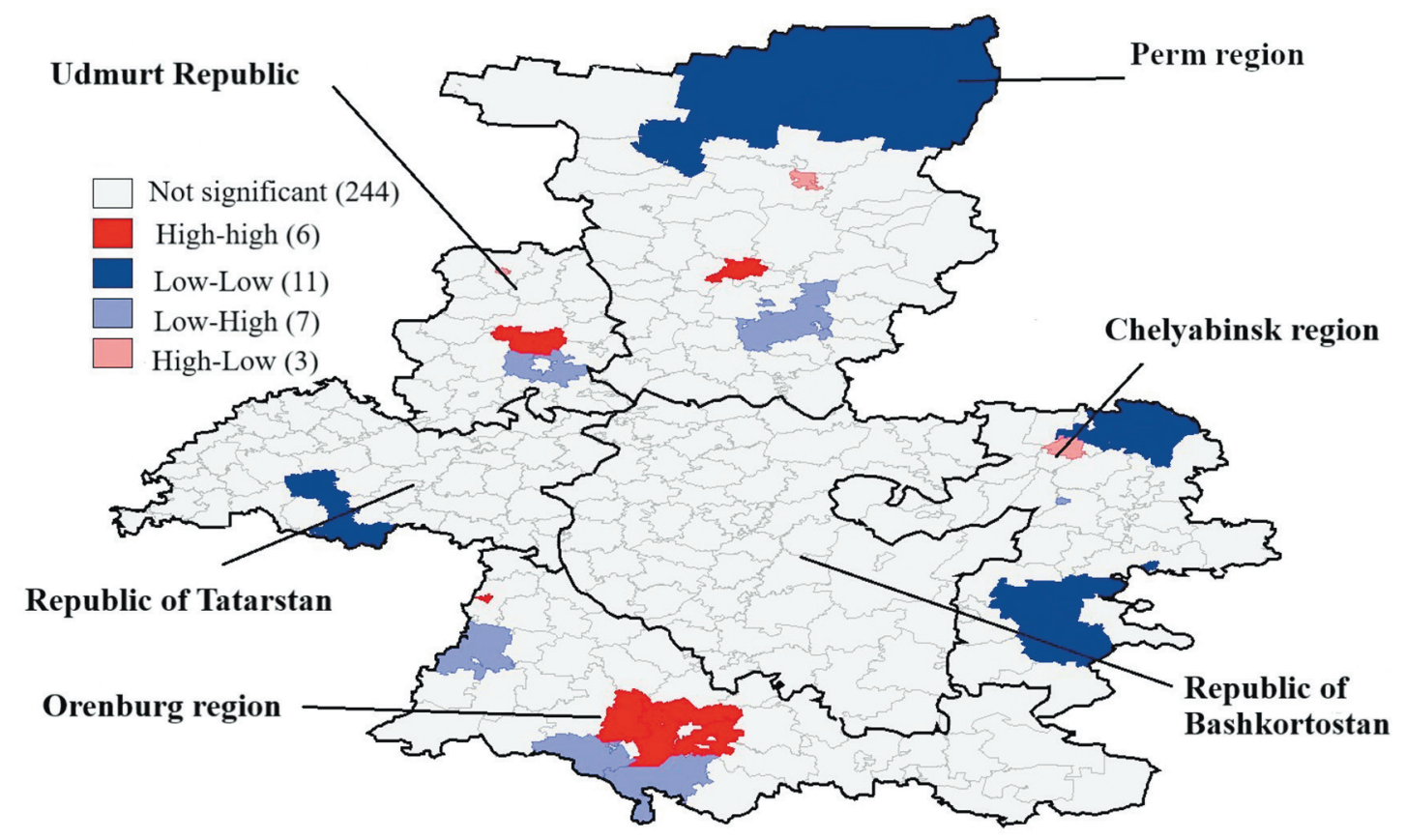

Fig. 3. Number of doctors: LISA cluster map $(p<0.05)$. Source: Rosstat statistics (processed by the author)

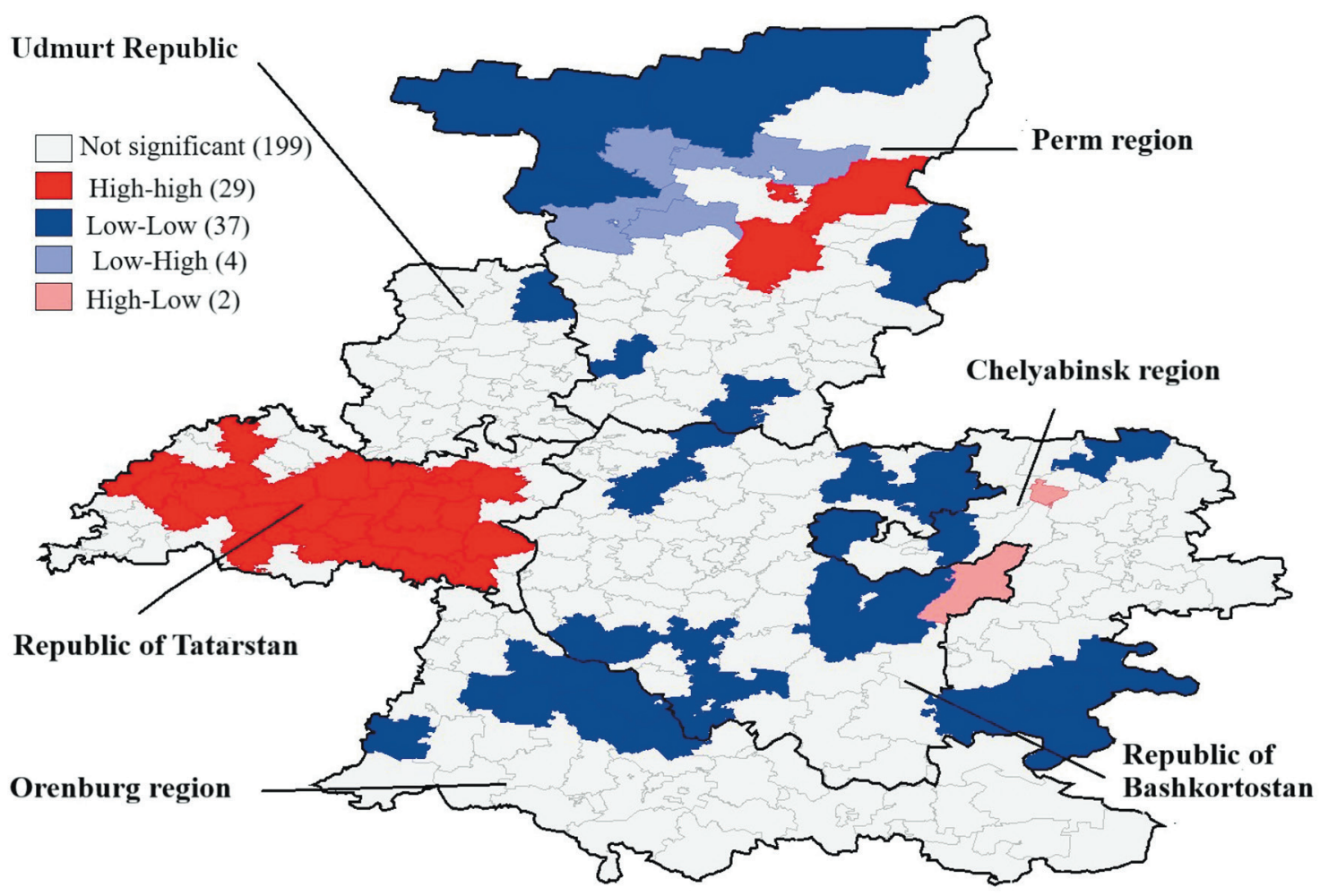

Fig. 4. Investments in fixed assets: LISA cluster map ( $p<0.05)$. Source: Rosstat statistics (processed by the author)

vices presented at each hierarchical scale providing the required level of medical care. There are no high-high location patterns out of administrative boundaries, so the potential of inter-regional interaction is absent.

Figure 4 considering investments in fixed assets shows a mixed picture.
Low-low core clusters are observed in all regions under consideration except for the Republic of Tatarstan. The Republic of Tatarstan shows favourable investment landscape, as high-high core clusters are covering almost the entire regional space. Its experience and replication potential may be used in other adjacent regions where in- 
vestments in fixed assets are beneficial to the polycentricity level (the Udmurt Republic and the Orenburg region).

\section{Conclusion}

Advantages of polycentric patterns (compared to monocentric ones) have been widely discussed in academic and political circles since the European Perspective of Spatial Planning came into force. Despite numerous insightful studies in this research field, the polycentric concept remains unclear both in theoretical and empirical ways while scant attention was paid to emerging economies. In the Russian context, the research question was whether the spatial structure depends on economic development and social and road infrastructure. An exploratory analysis of the impact of socio-economic characteristics of municipalities on polycentricity allowed me to conclude the following.

Firstly, such economic and social infrastructure variables as the value of shipped goods, performed works and services, as well as the number of doctors per 10,000 inhabitants have a positive impact on polycentricity. Traditional close ties of the labour force and industrial production patterns are still sufficiently strong. At the same time, a close correlation exists between polycentricity and the doctor coverage in municipalities.

Secondly, the evaluation of the cross-regional potential for cooperation showed an absence of spatial autocorrelation related to the number of doctors per 10,000 inhabitants. The high-high core clusters are located in the Udmurt Republic, as well as in the Orenburg and Perm regions. Due to strong economic disparities, my attempt to identify similar location core clusters of shipped production goods, performed works and services failed, thus I have calculated Moran's indexes using the data on investments in fixed assets. The estimates indicate high-high core clusters in the Republic of Tatarstan and the Perm region, upon which there are no horizontal intraregional ties between adjacent regions.

However, this study is not without limitations. Firstly, employment patterns depend on a wide range of factors. Thus, to improve the proposed ordinary least squares (OLS) regression model, such variables as the distance to the region's centre and climate conditions should be included.

Secondly, within the polycentric paradigm, the emphasis is placed on territory functions when establishing its role and position in the context of different hierarchical centres. This line of thought concerning the results achieved could be broadened to cover low-, middle-, and high-centrality public services (similar to foreign studies [7, 32]).

Thirdly, despite the execution of large infrastructure projects at the national level, matters of transport infrastructure planning and development in municipalities remain relevant. In this light, findings regarding the relationship between polycentricity and provision of transport infrastructure should provide municipal and regional authorities with the required information for decision-making. Moreover, this study deals only with the road infrastructure. Further studies should be aimed at infrastructural elements such as telecommunication infrastructure compensating for disadvantages arisen from distance and low density in peripheral areas. There are many fields (tele working, distance educational courses, etc.) where the provision of high-quality services at affordable prices would enhance regional development.

In conclusion, the given spatial structure requires new tools and strategic territorial development plans upon which the municipality is regarded as an initial unit of spatial planning. Examination of inter-municipal spatial effects will serve as the groundwork for further lines of research: identification of the centres' low-, middle-, high-centrality, establishment of effective territorial development areas, etc.

\section{References}

1. Salvati, L., Carlucci, M., Grigoriadis, E. \& Chelli, F. M. (2017). Uneven dispersion or adaptive polycentrism? Urban expansion, population dynamics and employment growth in an "ordinary" city. Review of Regional Research, 38(1), 1-25. DOI: $10.1007 / \mathrm{s} 10037-017-0115-x$.

2. Knaap, E., Ding, C., Niu, Y. \& Mishra, S. (2015). Polycentrism as a sustainable development strategy: empirical analysis from the state of Maryland. Journal of Urbanism: International Research on Placemaking and Urban Sustainability, 9(1), 73-92. DOI: 10.1080/17549175.2015.1029509.

3. Murakami, J. \& Chang, Z. (2018). Polycentric development under public leasehold: A spatial analysis of commercial land use rights. Regional Science and Urban Economics, 71, 25-36. DOI: 10.1016/j.regsciurbeco.2018.05.001.

4. Alonso, W. (1964). Location and Land Use. Towards a General Theory of Land Rent. Cambridge: Massachusetts, 204.

5. Li, Y. \& Liu, X. (2018). How did urban polycentricity and dispersion affect economic productivity? A case study of 306 Chinese cities. Landscape and Urban Planning, 173, 51-59. DOI: 10.1016/j.landurbplan.2018.01.007.

6. Kanai, J. M. \& Schindler, S. (2018). Peri-urban promises of connectivity: Linking project-led polycentrism to the infrastructure scramble. Environment and Planning A: Economy and Space, 51(1), 0308518X1876337. DOI: $10.1177 / 0308518 \times 18763370$. 
7. Rauhut, D. \& Komornicki, T. (2015). The Challenge of SGI Provision in Rural Areas. A paper prepared for the 55th European Congress of Regional Science International, 25-29 August 2015 in Lisbon, Portugal. Retrieved from: https://www. econstor.eu/handle/10419/124605 (Date of access: 13.03.2020).

8. Vasanen, A. (2012). Functional Polycentricity: Examining Metropolitan Spatial Structure through the Connectivity of Urban Sub-centres. Urban Studies, 49(16), 3627-3644. DOI: 10.1177/0042098012447000.

9. Dadashpoor, H., Afaghpoor, A. \& Allan, A. (2015). A methodology to assess the spatial configuration of urban systems in Iran from an interaction perspective. GeoJournal, 82(1), 109-129. DOI: 10.1007/s10708-015-9671-1

10. Zhong, C., Schläpfer, M., Müller Arisona, S., Batty, M., Ratti, C. \& Schmitt, G. (2016). Revealing centrality in the spatial structure of cities from human activity patterns. Urban Studies, 54(2), 437-455. DOI: 10.1177/0042098015601599.

11. Krehl, A. (2016). Urban subcentres in German city regions: Identification, understanding, comparison. Papers in Regional Science, 97, 79-104. DOI: 10.1111/pirs.12235.

12. Schmitt, P., Volgmann, K., Münter, A. \& Mitchell, R. (2015). Unpacking polycentricity at the city-regional scale: Insights from Dusseldorf and Stockholm. European Journal of Spatial Development, 59, 1-26.

13. Zambon, I., Serra, P., Grigoriadis, E., Carlucci, M. \& Salvati, L. (2017). Emerging urban centrality: An entropy-based indicator of polycentric development and economic growth. Land Use Policy, 68, 365-371. DOI: 10.1016/j.landusepol.2017.07.063.

14. Davoudi, S. (2003). EUROPEAN BRIEFING: Polycentricity in European spatial planning: from an analytical tool to a normative agenda. European Planning Studies, 11(8), 979-999. DOI: 10.1080/0965431032000146169.

15. Riguelle, F., Thomas, I. \& Verhetsel, A. (2007). Measuring urban polycentrism: a European case study and its implications. Journal of Economic Geography, 7, 193-215.

16. Aguilera, A. \& Mignot, D. (2004). Urban Sprawl, polycentrism and commuting. A comparison of Seven French Urban Areas. Urban Public Economics Review, 1, 93-113.

17. Taubenböck, H., Standfuß, I., Wurm, M., Krehl, A. \& Siedentop, S. (2017). Measuring morphological polycentricity - a comparative analysis of urban mass concentrations using remote sensing data. Computers, Environment and Urban Systems, 64, 42-56. DOI: 10.1016/j.compenvurbsys.2017.01.005.

18. Parr, J. (2004). The Polycentric Urban Region: a Closer Inspection. Regional Studies, 38(3), 231-240.

19. Vasanen, A. (2013). Spatial Integration and Functional Balance in Polycentric Urban Systems: A Multi-Scalar Approach. Tijdschrift Voor Economische En Sociale Geografie [Journal of Economic \& Social Geography], 104(4), 410-425. DOI: $10.1111 /$ tesg.12029.

20. Yang, L., Wang, Y., Bai, Q. \& Han, S. (2018). Urban Form and Travel Patterns by Commuters: Comparative Case Study of Wuhan and Xian, China. Journal of Urban Planning and Development, 144(1), 05017014. DOI: 10.1061/(asce) up.1943-5444.0000417.

21. Hu, L., Sun, T. \& Wang, L. (2018). Evolving urban spatial structure and commuting patterns: A case study of Beijing, China. Transportation Research Part D: Transport and Environment, 59, 11-22. DOI: 10.1016/j.trd.2017.12.007.

22. Meijers, E. (2008). Summing Small Cities Does Not Make a Large City: Polycentric Urban Regions and the Provision of Cultural, Leisure and Sports Amenities. Urban Studies, 45(11), 2323-2342. DOI: 10.1177/0042098008095870.

23. Brezzi, M. \& Veneri, P. (2014). Assessing Polycentric Urban Systems in the OECD: Country, Regional and Metropolitan Perspectives. European Planning Studies, 23(6), 1128-1145. doi:10.1080/09654313.2014.905005.

24. Wen, H. \& Tao, Y. (2015). Polycentric urban structure and housing price in the transitional China: Evidence from Hangzhou. Habitat International, 46, 138-146. DOI: 10.1016/j.habitatint.2014.11.006.

25. Minakir, P. A. (2016). The National Strategy of Spatial Development: Is It the Conscientious Delusion or Deliberate Simplification? Prostranstvennaya ekonomika [Spatial Economics], 3, 7-15. (In Russ.)

26. Kurushina, E. V. \& Petrov, M. B. (2018). Performance Criteria of Spatial Development Projects Based on Interregional Integration. Ekonomika regiona [Economy of Region], 14(1), 176-189. DOI: 10.17059/2018-1-14.

27. Veneri, P., \& Burgalassi, D. (2012). Questioning Polycentric Development and its Effects. Issues of Definition and Measurement for the Italian NUTS-2 Regions. European Planning Studies, 20(6), 1017-1037.

28. Meijers, E. (2008). Summing Small Cities Does Not Make a Large City: Polycentric Urban Regions and the Provision of Cultural, Leisure and Sports Amenities. Urban Studies, 45(11), 2323-2342.

29. Moran, P. (1948). The interpretation of statistical maps. Journal of the Royal Statistical Society. Series B, 10, $243-251$.

30. Geary, R. (1954). The continuity ratio and statistical mapping. The Incorporated Statistician, 5, 115-145.

31. Anselin, L. (1990). Spatial Dependence and Spatial Structural Instability in Applied Regression Analysis. Journal of Regional science, 30, 185-207.

32. Milbert, A., Breuer, I. M., Rosik, P., Stępniak, M. \& Velasco, X. (2013). Accessibility of Services of General Interest in Europe. Romanian Journal of Regional Science, 7(Special Issue June), 37-65.

\section{About the author}

Dina Kh. Krasnoselskaya - Cand. Sci. (Econ.), Associate Professor, Institute of Business Ecosystems and Creative Industries, Ufa State Petroleum Technological University; http://orcid.org/0000-0002-1668-2937, Researcher ID: F-20822019 (1, Kosmonavtov St., Ufa, 450062, Republic of Bashkortostan, Russian Federation, e-mail: dina-hamzina@mail.ru). 


\section{Информация об авторе}

Красносельская Дина Хадимовна - кандидат экономических наук, доцент, Институт экосистем бизнеса и креативных индустрий, доцент, Уфимский государственный нефтяной технический университет; http://orcid. org/0000-0002-1668-2937, Researcher ID F-2082-2019 (Российская Федерация, 450062, Республика Башкортостан, г. Уфа, ул. Космонавтов, 1; e-mail: dina-hamzina@mail.ru).

Дата поступления рукописи: 27.11.2019.

Прошла рецензирование: 10.03.2020.

Принято решение о публикаиии: 23.03.2021.

Received: 27 Nov 2020

Reviewed: 10 Mar 2020

Accepted: 23 Mar 2021 